\title{
Effects of HER2 status on the prognosis of male breast cancer: a population-based study
}

This article was published in the following Dove Press journal:

OncoTargets and Therapy

\author{
Liang Chen \\ Yi Ming Weng \\ Meng Xue Hu \\ Min Peng \\ Qi Bin Song
}

Department of Oncology, Renmin Hospital of Wuhan University, Wuhan, Hubei Province 430060, People's

Republic of China
Correspondence: Min Peng; Qi Bin Song Department of Oncology, Renmin Hospital of Wuhan University, No. 238 Jiefang Road, Wuhan, Hubei Province 430060, People's Republic of China

Tel +86278 804 | 9 | I

Fax +86 278804 |9|।

Email mpeng320@whu.edu.cn; qibinsong@163.com
Objective: This study was designed to analyze the effects of human epidermal growth factor receptor-2 (HER2) status on the prognosis of male breast cancer (MBC).

Methods: The SEER database was used to identify MBC patients diagnosed between 2010 and 2015. Patients were divided into HER2-negative and HER2-positive groups and chisquare test was used to compare the demographics. Propensity score matching (PSM) was used to remove confounding factors. The log-rank test was used to compare the overall survival (OS) and disease-specific survival (DSS) between the two groups. Univariate and multivariate Cox regression analyses were used to evaluate the effects of different variables on the prognosis of MBC patients. Subgroup analysis was conducted by using R software to explore the benefit of OS and DSS in the subgroup of MBC patients.

Results: In the matched cohort, the log-rank test showed that there was a longer OS $(P=0.044)$ in the HER2-negative group, and the 4-year OS rate in HER2-negative patients was significantly improved $(P=0.008)$, but there was no difference in the DSS $(P=0.408)$ and the 4-year DSS rates $(P=0.198)$ between the two groups. Univariate and multivariate Cox regression also showed that the HER2 status did not independently associate with DSS $(P=0.444)$. Subgroup analysis showed that HER2-negative patients experienced a longer OS in the subgroup of tumors $2-4 \mathrm{~cm}$ in size, no distant metastasis and who had received radiotherapy, but none of subgroup was found a significant difference in DSS between different HER2 status.

Conclusion: This study identified that HER2 status had a clear influence on OS in patients with MBC, and there was a longer OS and a higher 4-year OS rate in the HER2-negative group. In addition, we observed that HER2 status had no significant effect on DSS in patients with MBC.

Keywords: male breast cancer, HER2 status, overall survival, disease-specific survival

\section{Background}

The morbidity and mortality of breast cancer rank first among females worldwide. ${ }^{1}$ However, male breast cancer (MBC) is a rare disease with an incidence of $<1 \%$ in all breast cancer patients. ${ }^{2}$ Although the geographical distribution of $\mathrm{MBC}$ is similar to that of female breast cancer (FBC), with higher rates in North America and Europe and lower rates in Asia, there are different biological characteristics between $\mathrm{MBC}$ and $\mathrm{FBC}$ patients. ${ }^{3}$ In recent decades, the incidence of $\mathrm{MBC}$ has increased globally. ${ }^{4}$ Therefore, it is important to focus on the prognostic factors and treatment strategies of MBC.

Human epidermal growth factor receptor-2 (HER2) is a transmembrane glycoprotein with tyrosine kinase activity, which plays an important role in controlling 
epithelial cell growth and differentiation. ${ }^{5}$ HER2-positive cases account for about $20-25 \%$ in FBC patients, which is more invasive and has a poor prognosis. ${ }^{6,7}$ Trastuzumab is a humanized IgG1 kappa monoclonal antibody, which consists of two antigen-specific sites that selectively bind, with high affinity, the extracellular domain of the human HER2 receptor. ${ }^{8}$ Trastuzumab has significantly improved the survival outcome of HER2-positive FBC patients. $^{9-11}$

The therapeutic methods for MBC were unclear because of its rare incidence and the lack of prospective clinical study data. ${ }^{12}$ To date, the treatment of MBC follows almost the same indications as female postmenopausal breast cancer. Because there have been few clinical trials on the treatment of MBC, most oncologists base their treatment recommendations on their personal experience with the disease and on the results of studies of FBC. ${ }^{13}$ In the latest National Comprehensive Cancer Network guideline, trastuzumab is recommended for postoperative adjuvant therapy in patients with HER2-positive early breast cancer or first-line treatment of advanced HER2-positive breast cancer. Previous studies indicate that about $15 \%$ of MBC cases showed HER2-positive. ${ }^{14}$ Because of the few HER2-positive MBC patients, trastuzumab has been used only in some cases. ${ }^{15-17}$ So far, there is insufficient evidence to support the use of trastuzumab in MBC patients. Overexpression of HER2 is a well-known prognostic factor associated with poor survival in FBC patients; by contrast, the association between HER2 overexpression and survival is still debated in MBC. ${ }^{18}$ In short, the effect of HER2 status on the prognosis of patients with MBC has not been clearly reported, and the efficacy of targeted drugs for MBC patients has not been clarified. In this study, we extracted the most recent data from the SEER database to analyze the effects of HER2 status on the prognosis of patients with $\mathrm{MBC}$, expecting to provide more evidence for the clinical treatment of MBC.

\section{Materials and methods}

The SEER database is one of the most representative tumor registration databases in North America, established by the National Cancer Institute in 1973. The SEER Stat statistical software (version 8.3.5) was used to identify MBC patients diagnosed between 2010 and 2015. Inclusion criteria were as follows: breast cancer, male patients, and clear follow-up data. Exclusion criteria were as follows: the breast was not the only primary site, breast cancer was not confirmed by histology, and HER2 status was borderline or unknown. HER2-positive is defined as $3+$ on immunohistochemistry or fluorescence in situ hybridization-amplified. The study population selection is shown in Figure 1.

The information on age, pathological type, degree of differentiation, tumor size, American Joint Committee on Cancer (AJCC, 7th edition) stage, regional node metastasis, distant metastasis, HER2 status, surgery, radiation, chemotherapy, survival status, survival time, and cause of

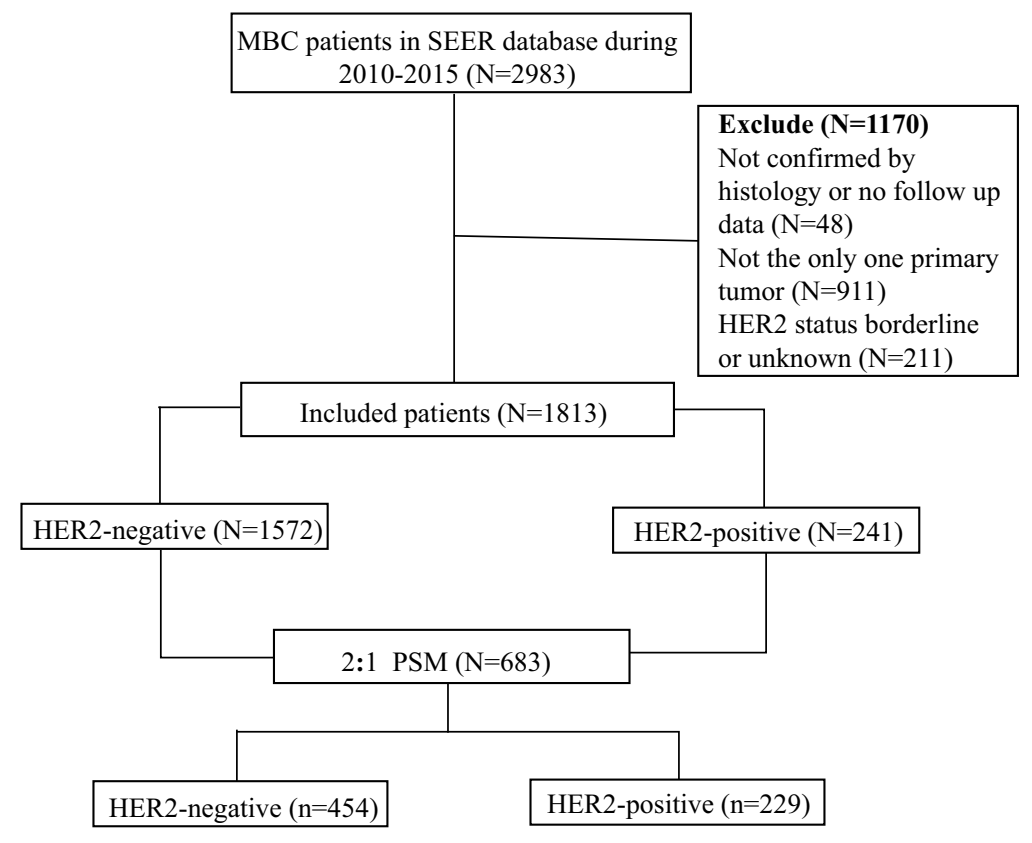

Figure I Flowchart of study population selection. 
death was extracted. The outcomes of interest were disease-specific survival (DSS) and overall survival (OS). DSS was defined as the date of diagnosis to the date of breast cancer death, and OS was defined as the interval from diagnosis to death from any cause. This study was approved by the Ethics Committee of our hospital, namely Wuhan University Renmin Hospital Ethics Committee, and written informed consent was waived.

X-tile software was used to analyze the optimal cutoff point of age and tumor size based on the OS of MBC patients. Patients were divided into HER2-positive and HER2-negative groups according to different HER2 status. To ensure well-balanced characteristics for the two comparisons, propensity score matching (PSM) with 2:1 proportion was conducted using $\mathrm{R}$ software. The chi-square test was used to compare the demographics of both groups, and the log-rank test was used to compare the difference in OS and DSS between two groups. The Z-test was used to compare the 4-year OS and DSS rates in HER2-negative and HER2-positive patients according to the KaplanMeier curve. Univariate and multivariate Cox regression analyses were used to evaluate the independent association of different variables with OS and DSS. If the $P$-value less than 0.05 in the univariate analysis or the clinical significance of the variable is worth exploring, we included the variable in the multivariate analysis. Hazard ratios and their 95\% CIs were estimated using the Cox model. Subgroup analysis of the effects on OS and DSS in patients with different HER2 status was conducted using R software. Statistical analysis was performed using SPSS Statistics 23.0 software (IBM Corp, Armonk, NY, USA). All statistical tests were two-sided $P$-values and $P<0.05$ was considered statistically significant.

\section{Results}

A total of 1813 patients with $\mathrm{MBC}$ were enrolled in the study, of which 1572 cases were HER2-negative and 241 cases were HER2-positive. HER2-positive cases accounted for approximately $13.3 \%$ among all MBC patients. The median follow-up time was 27 months. The 3 -year and 5-year survival rates were $84.8 \%$ and $74.6 \%$. The chi-square test results showed that the distribution of HER2 status was influenced by age $(P<0.001)$, degree of differentiation $(P<0.001)$, AJCC stage $(P<0.001)$, tumor size $(P<0.001)$, regional node metastasis $(P=0.004)$, distant metastasis $(P=0.002)$, surgery $(P<0.001)$, and chemotherapy $(P<0.001)$. To reduce selection bias and imbalanced distributions of confounding factors, PSM was conducted by R software. PSM was performed using $2: 1$ nearest neighbor matching with a caliper of 0.01 to accept a matched pair. Then, 454 cases of HER2-negative patients and 229 cases of HER2-positive patients were enrolled in this matched cohort study. In the matched cohort, there was no significant difference in the distribution of HER2-positive and HER-2 negative patients in terms of age $(P=0.303)$, pathological type $(P=0.270)$, degree of differentiation $(P=0.963)$, AJCC stage $(P=0.281)$, tumor size $(P=0.669)$, distant metastasis $(P=0.217)$, surgery $(P=0.080)$, radiation $(P=0.643)$, or chemotherapy $(P=0.661)$. Demographic and clinical characteristics are shown in Table 1.

\section{Kaplan-Meier curve of MBC patients with different HER2 status}

The log-rank test was used to compare the difference in OS and DSS between patients with different HER2 status. Kaplan-Meier curves for MBC patients with different HER2 status are shown in Figure 2. The 4-year OS and DSS rates were analyzed according to the Kaplan-Meier curve. Furthermore, the Z-test was used to compare the 4-year OS and DSS rates between the two groups. In the unmatched cohort, the OS $(P=0.013)$ was longer and the 4-year OS rate $(P=0.005)$ was significantly improved in the HER2-negative group, but there were no significant difference in DSS $(P=0.059)$ and the 4-year DSS rate $(P=0.091)$ between the two groups. When matched the cohort, the HER2-negative group also experienced a longer $\operatorname{OS}(P=0.044)$ and a benefit of the 4-year OS rate $(P=0.008)$, but there were no significant differences in DSS $(P=0.408)$ and the 4-year DSS rate $(P=0.198)$. Results of the 4-year OS and DSS rates with different HER2 status are shown in Table 2.

\section{Univariable and multivariable Cox regression for OS and DSS}

Univariate and multivariate Cox regression analyses were performed in the matched cohort. The univariate analysis showed that there was a significant difference in OS $(P=0.046)$ between the two groups. Moreover, age at diagnosis, tumor size, regional node metastasis, distant metastasis, surgery, and chemotherapy were also significantly associated with OS. In contrast, the univariate analysis did not show a significant difference in $\operatorname{DSS}(P=0.410)$ for different HER2 status. Multivariate Cox analysis confirmed that HER2 status was not an independent associated factor with DSS $(P=0.548)$. However, the independent 
Table I Demographic and clinical characteristics of MBC patients

\begin{tabular}{|c|c|c|c|c|c|c|c|c|}
\hline \multirow[t]{2}{*}{ Characteristics } & \multicolumn{4}{|c|}{ Unmatched cohort } & \multicolumn{4}{|c|}{ Matched cohort } \\
\hline & $N=|8| 3$ & $\begin{array}{l}\text { HER2- } \\
\text { negative } \\
(n=1572)\end{array}$ & $\begin{array}{l}\text { HER2- } \\
\text { positive } \\
(n=24 I)\end{array}$ & $P$-value & $N=683$ & $\begin{array}{l}\text { HER2- } \\
\text { negative } \\
(n=454)\end{array}$ & $\begin{array}{l}\text { HER2- } \\
\text { positive } \\
(n=229)\end{array}$ & $P$-value \\
\hline $\begin{array}{l}\text { Age at diagnosis } \\
\text { (years, \%) } \\
\leq 65 \\
66-80 \\
\geq 8 \mathrm{I} \\
\text { Pathological type (\%) }\end{array}$ & $\begin{array}{l}884 \\
703 \\
226\end{array}$ & $\begin{array}{l}736(46.8 \%) \\
628(39.9 \%) \\
208(13.2 \%)\end{array}$ & $\begin{array}{l}148(61.4 \%) \\
75(31.1 \%) \\
18(7.5 \%)\end{array}$ & $\begin{array}{l}<0.001 \\
0.087\end{array}$ & $\begin{array}{l}389 \\
247 \\
17\end{array}$ & $\begin{array}{l}252(55.5 \%) \\
173(38.1 \%) \\
29(6.4 \%)\end{array}$ & $\begin{array}{l}137(59.8 \%) \\
74(32.3 \%) \\
18(7.9 \%)\end{array}$ & $\begin{array}{l}0.303 \\
0.270\end{array}$ \\
\hline $\begin{array}{l}\text { Invasive ductal } \\
\text { Other }\end{array}$ & $\begin{array}{l}1628 \\
185\end{array}$ & $\begin{array}{l}\text { I } 404 \text { (89.3\%) } \\
\text { I } 68 \text { (I0.7\%) }\end{array}$ & $\begin{array}{l}224 \text { (92.9\%) } \\
17(7.1 \%)\end{array}$ & & $\begin{array}{l}648 \\
35\end{array}$ & $\begin{array}{l}434 \text { (95.6\%) } \\
20(4.4 \%)\end{array}$ & $\begin{array}{l}214(93.4 \%) \\
15(6.6 \%)\end{array}$ & \\
\hline $\begin{array}{l}\text { Differentiation (\%) } \\
\text { Well } \\
\text { Moderate } \\
\text { Poor/undifferentiated } \\
\text { Unknown }\end{array}$ & $\begin{array}{l}204 \\
903 \\
621 \\
85\end{array}$ & $\begin{array}{l}197(12.5 \%) \\
808(51.4 \%) \\
499(41.7 \%) \\
68(4.3 \%)\end{array}$ & $\begin{array}{l}7(2.9 \%) \\
95(39.4 \%) \\
122(50.6 \%) \\
17(7.1 \%)\end{array}$ & $<0.001$ & $\begin{array}{l}24 \\
260 \\
359 \\
40\end{array}$ & $\begin{array}{l}17(3.7 \%) \\
17 \mid(37.7 \%) \\
239(52.6 \%) \\
27(5.9 \%)\end{array}$ & $\begin{array}{l}7(3.1 \%) \\
89(38.9 \%) \\
120(52.4 \%) \\
13(5.7 \%)\end{array}$ & 0.963 \\
\hline $\begin{array}{l}\text { AJCC stage (\%) } \\
\text { I } \\
\text { II } \\
\text { III } \\
\text { IV } \\
\text { Unknown }\end{array}$ & $\begin{array}{l}569 \\
751 \\
301 \\
151 \\
41\end{array}$ & $\begin{array}{l}521(33.1 \%) \\
653(41.5 \%) \\
248(15.8 \%) \\
119(7.6 \%) \\
31(2.0 \%)\end{array}$ & $\begin{array}{l}48(19.9 \%) \\
98(40.7 \%) \\
53(22.0 \%) \\
32(13.3 \%) \\
10(4.1 \%)\end{array}$ & $<0.001$ & $\begin{array}{l}133 \\
293 \\
167 \\
72 \\
18\end{array}$ & $\begin{array}{l}85(18.7 \%) \\
199(43.8 \%) \\
115(25.3 \%) \\
47(10.4 \%) \\
8(1.8 \%)\end{array}$ & $\begin{array}{l}48(21.0 \%) \\
94(41.0 \%) \\
52(22.7 \%) \\
25(10.9 \%) \\
10(4.4 \%)\end{array}$ & $0.28 I$ \\
\hline $\begin{array}{l}\text { Tumor size (\%) } \\
\qquad 2 \mathrm{~cm} \\
2-4 \mathrm{~cm} \\
>4 \mathrm{~cm} \\
\text { Unknown }\end{array}$ & $\begin{array}{l}664 \\
872 \\
206 \\
71\end{array}$ & $\begin{array}{l}599(38.1 \%) \\
751(47.8 \%) \\
163(10.4 \%) \\
59(3.8 \%)\end{array}$ & $\begin{array}{l}65(27.0 \%) \\
121(50.2 \%) \\
43(17.8 \%) \\
12(5.0 \%)\end{array}$ & $<0.001$ & $\begin{array}{l}192 \\
366 \\
101 \\
24\end{array}$ & $\begin{array}{l}127(28.0 \%) \\
249(54.8 \%) \\
64(14.1 \%) \\
14(3.1 \%)\end{array}$ & $\begin{array}{l}65(28.4 \%) \\
117(51.1 \%) \\
37(16.2 \%) \\
10(4.4 \%)\end{array}$ & 0.669 \\
\hline \multicolumn{2}{|c|}{ Regional node metastasis (\%) } & & & 0.004 & & & & 0.030 \\
\hline $\begin{array}{l}\text { No } \\
\text { Yes } \\
\text { Unknown }\end{array}$ & $\begin{array}{l}843 \\
725 \\
245\end{array}$ & $\begin{array}{l}753(47.9 \%) \\
618(39.3 \%) \\
201(12.8 \%)\end{array}$ & $\begin{array}{l}90(37.3 \%) \\
107(44.4 \%) \\
44(18.3 \%)\end{array}$ & & $\begin{array}{l}253 \\
345 \\
85\end{array}$ & $\begin{array}{l}165(36.3 \%) \\
242(53.3 \%) \\
47(10.4 \%)\end{array}$ & $\begin{array}{l}88(38.4 \%) \\
103(45.0 \%) \\
38(16.6 \%)\end{array}$ & \\
\hline $\begin{array}{l}\text { Distant metastasis (\%) } \\
\text { No } \\
\text { Yes } \\
\text { Unknown }\end{array}$ & $\begin{array}{l}1622 \\
151 \\
40\end{array}$ & $\begin{array}{l}1422(90.5 \%) \\
119(7.6 \%) \\
31(2.0 \%)\end{array}$ & $\begin{array}{l}200(83 \%) \\
32(13.3 \%) \\
9(3.7 \%)\end{array}$ & 0.002 & $\begin{array}{l}594 \\
72 \\
17\end{array}$ & $\begin{array}{l}399(87.9 \%) \\
47(10.4 \%) \\
8(1.8 \%)\end{array}$ & $\begin{array}{l}195(85.2 \%) \\
25(10.9 \%) \\
9(3.9 \%)\end{array}$ & 0.217 \\
\hline $\begin{array}{l}\text { Surgery (\%) } \\
\text { No/unknown } \\
\text { Yes }\end{array}$ & $\begin{array}{l}164 \\
1633\end{array}$ & $\begin{array}{l}\mid 35 \text { (8.6\%) } \\
\mid 437 \text { (9I.4\%) }\end{array}$ & $\begin{array}{l}45(18.7 \%) \\
196(81.3 \%)\end{array}$ & $<0.001$ & $\begin{array}{l}82 \\
601\end{array}$ & $\begin{array}{l}47 \text { (10.4\%) } \\
407 \text { (89.6\%) }\end{array}$ & $\begin{array}{l}35(15.3 \%) \\
194(84.7 \%)\end{array}$ & 0.080 \\
\hline $\begin{array}{l}\text { Radiation (\%) } \\
\text { No/unknown } \\
\text { Yes }\end{array}$ & $\begin{array}{l}1319 \\
494\end{array}$ & $\begin{array}{l}\text { II } 35 \text { (72.2\%) } \\
437 \text { (27.8\%) }\end{array}$ & $\begin{array}{l}184(76.3 \%) \\
57(23.7 \%)\end{array}$ & 0.187 & $\begin{array}{l}507 \\
176\end{array}$ & $\begin{array}{l}334(73.6 \%) \\
120(26.4 \%)\end{array}$ & $\begin{array}{l}173(75.5 \%) \\
56(24.5 \%)\end{array}$ & 0.643 \\
\hline $\begin{array}{l}\text { Chemotherapy (\%) } \\
\text { No/unknown } \\
\text { Yes }\end{array}$ & $\begin{array}{l}1088 \\
725\end{array}$ & $\begin{array}{l}1014(64.5 \%) \\
558(35.5 \%)\end{array}$ & $\begin{array}{l}74(30.7 \%) \\
167(69.3 \%)\end{array}$ & $<0.001$ & $\begin{array}{l}212 \\
471\end{array}$ & $\begin{array}{l}138(30.4 \%) \\
316(69.6 \%)\end{array}$ & $\begin{array}{l}74(32.3 \%) \\
155(67.7 \%)\end{array}$ & 0.661 \\
\hline
\end{tabular}



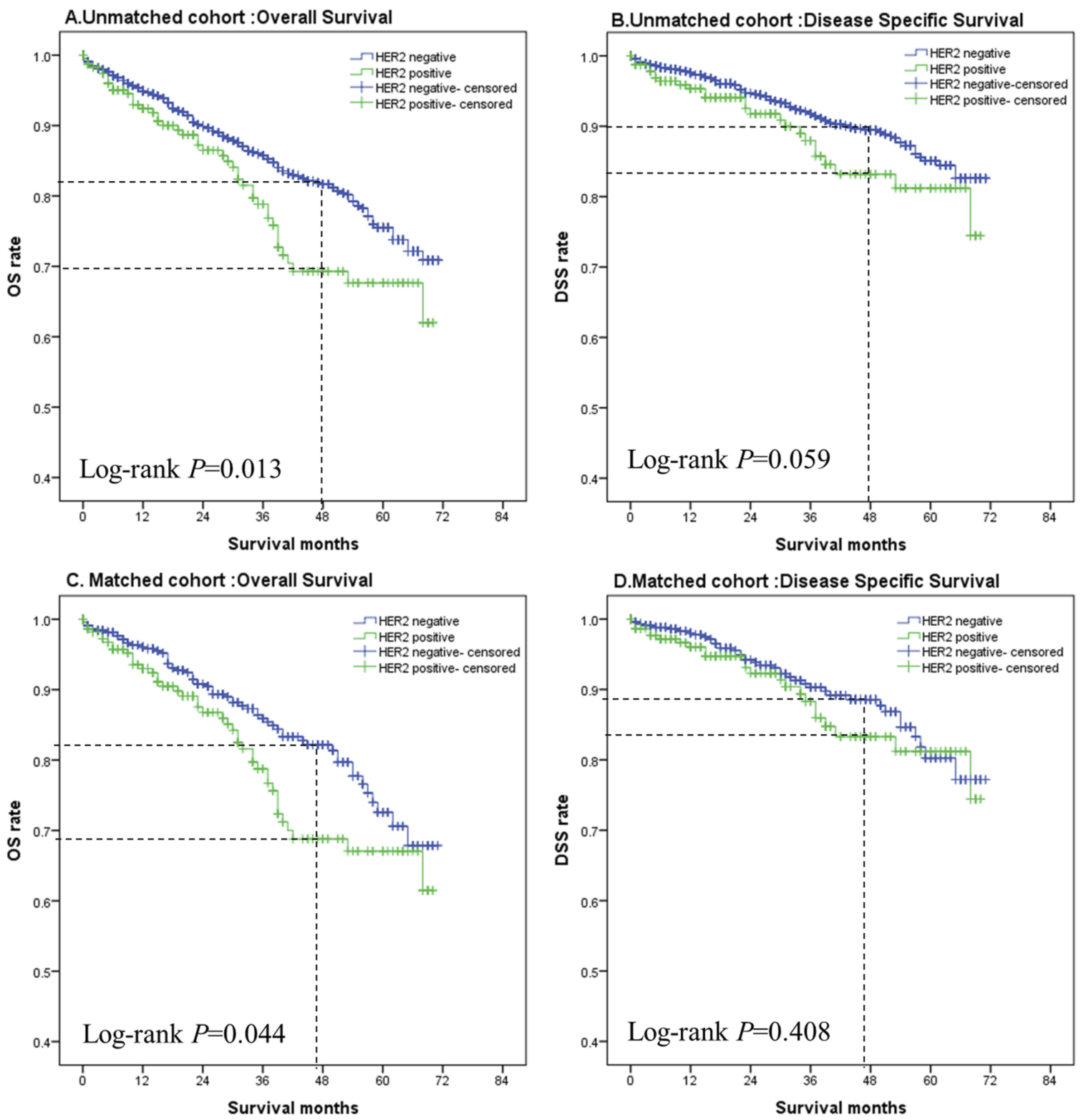

Figure 2 Kaplan-Meier curves of MBC patients with different HER2 status.

Notes: Unmatched cohort: overall survival (A), disease-specific survival (B); matched cohort: overall survival (C), disease-specific survival (D).

Table 2 Comparison of 4-year OS and DSS with different HER2 status

\begin{tabular}{|l|l|l|l|l|}
\hline \multirow{2}{*}{ HER2 status } & \multicolumn{2}{l|}{ Unmatched cohort } & \multicolumn{2}{l|}{ Matched cohort } \\
\cline { 2 - 5 } & 4-year OS & 4-year DSS & 4-year OS & 4-year DSS \\
\hline HER2-negative & 0.817 & 0.894 & 0.821 & 0.886 \\
HER2-positive & 0.693 & 0.832 & 0.688 & 0.833 \\
P-value & 0.005 & 0.091 & 0.008 & 0.198 \\
\hline
\end{tabular}

associated factors with DSS were pathological type metastasis $(P<0.001)$, and surgery $(P=0.019)$. The results $(P=0.033)$, regional nodes metastasis $(P=0.047)$, distant are shown in Table 3 . 


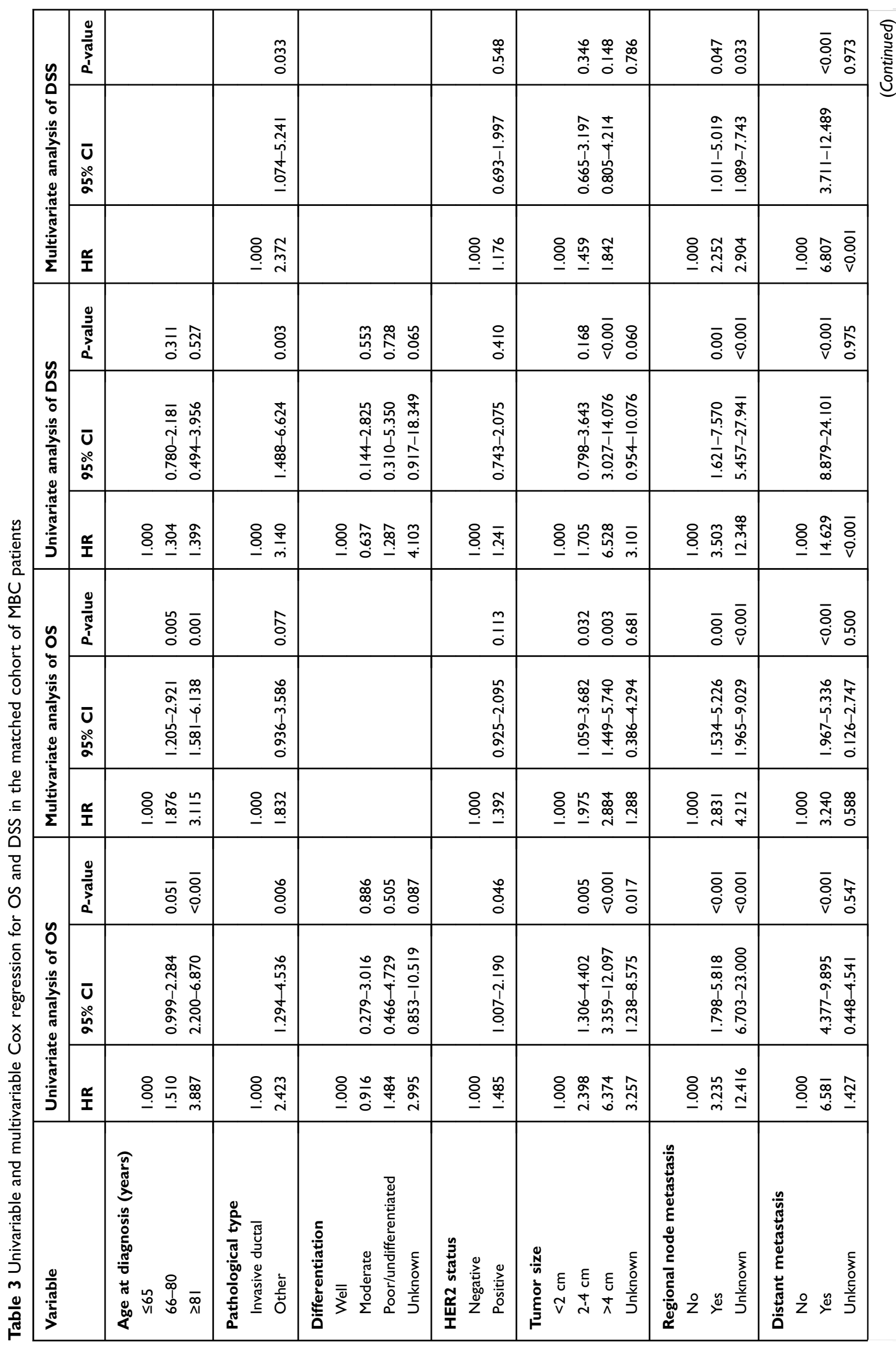




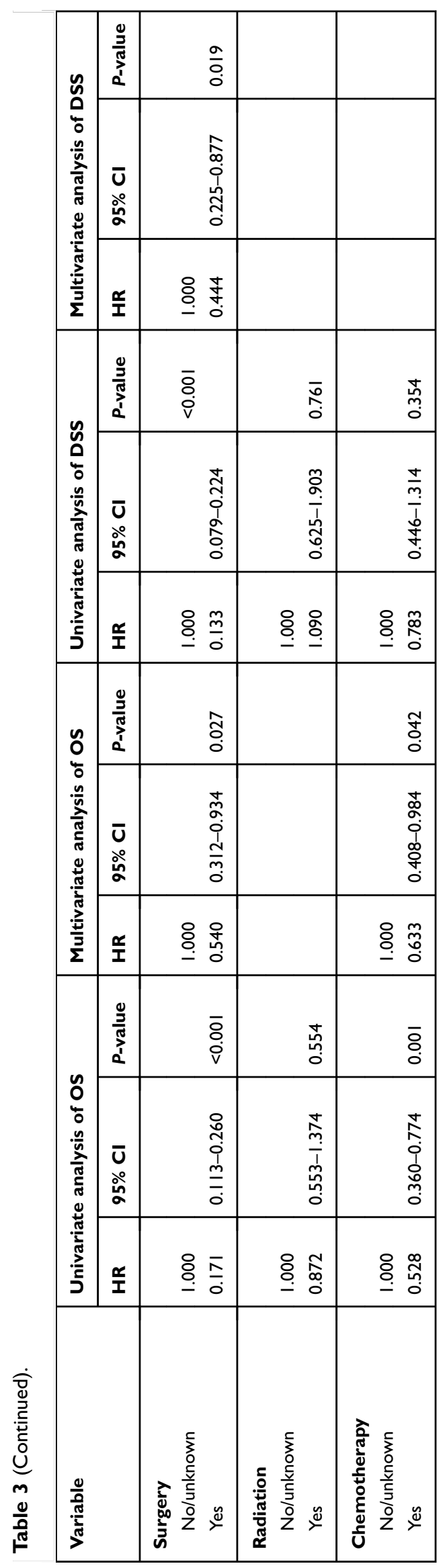

\section{Subgroup analysis of the effects on OS and DSS in patients with different HER2 status}

To further explore the possible benefits of OS and DSS in the subgroup of MBC patients, subgroup analysis was performed according to different HER2 status. The forest map showed that there were significant differences between different HER2 status in the subgroup of who had a tumor size of $2-4 \mathrm{~cm}$ $(P=0.020)$, no distant metastasis $(P=0.023)$ and who had received radiotherapy $(P=0.041)$, in which the HER2-negative patients experienced a longer OS when compared with HER2positive patients. However, none of the subgroup was found to have a significant difference in DSS between different HER2 status. The result is shown in Figure 3.

\section{Discussion}

Currently, information about prognostic factors and treatment strategies in MBC is controversial. Studies have shown that patients with $\mathrm{MBC}$ have a worse prognosis than those with FBC. ${ }^{19}$ The unstandardized OS rate of patients with MBC is lower than that of patients with $\mathrm{FBC}$, which may be related to the older age, late stage, and shorter life expectancy in men diagnosed with breast cancer. ${ }^{20-22}$ The different biological characteristics between $\mathrm{MBC}$ and FBC may also because of the different survival outcome. ${ }^{21,23}$ In patients with $\mathrm{MBC}$, the rate of hormone receptor-positive cancer is higher than that in the hormone receptor-negative group, while the rate of HER2-positive cancer is lower than that of HER2-negative cancer. ${ }^{21,24}$ The HER2-positive rate in the current study is approximately $13.3 \%$, which is almost consistent with previous reports. ${ }^{18}$ At present, endocrine therapy is the most important treatment for systemic therapy in patients with hormone receptor-positive MBC, which has significantly improved the prognosis of patients with hormone receptor-positive $\mathrm{MBC}{ }^{25}$ However, it was rarely reported that targeted therapy had been used for MBC.

A previous study had shown significant differences in survival according to HER2 status and to identify the prognostic role of HER2 in MBC. Leone et $\mathrm{al}^{26}$ found that HER2positive patients have shorter OS (hazard ratio 1.90, $P=0.031$ ) when compared with HER2-negative patients, which are consistent with the current study results that HER2-positive patients have a shorter OS and the 4-year OS rate was significantly improved. However, Arslan UY et $\mathrm{al}^{27}$ showed there was no significant difference in OS $(P=0.30)$ between HER2-positive and HER2-negative MBC patients, but MBC patients with HER2-positive have 


\section{A. Subgroup analysis of OS}

\begin{tabular}{|c|c|c|}
\hline Subgroup and ysis & HER2 neggaive & HER2 positive \\
\hline All Psierts & 454 & 229 \\
\hline \multicolumn{3}{|l|}{ Age si disgrosis } \\
\hline$<66$ & 252 & 137 \\
\hline $66-80$ & 173 & 74 \\
\hline$>80$ & 29 & 18 \\
\hline \multicolumn{3}{|l|}{ Pathological type } \\
\hline Imsaive ducts & 434 & 214 \\
\hline Other & 20 & 15 \\
\hline \multicolumn{3}{|l|}{ Tumor size } \\
\hline$<2 \mathrm{~m}$ & 127 & 65 \\
\hline $24 \mathrm{om}$ & 249 & 117 \\
\hline $24 \mathrm{om}$ & 64 & 37 \\
\hline \multirow{2}{*}{\multicolumn{3}{|c|}{$\begin{array}{l}\text { Uriknown } \\
\text { Regiontal nodes melastysis }\end{array}$}} \\
\hline & & \\
\hline No & 165 & 68 \\
\hline Yes & 242 & 103 \\
\hline Urkinown & & \\
\hline \multicolumn{3}{|l|}{ Distart metselsyis } \\
\hline No & 399 & 195 \\
\hline Yes & 47 & 25 \\
\hline Urkinown & & \\
\hline \multicolumn{3}{|l|}{ Surgery } \\
\hline Nolurkinown & 47 & 35 \\
\hline Yes & 407 & 194 \\
\hline \multicolumn{3}{|l|}{ Rasiafion } \\
\hline Nolurkriowr & 334 & 173 \\
\hline Yes & 120 & 56 \\
\hline \multicolumn{3}{|l|}{ Chematherapy } \\
\hline Nolurkniomi & 138 & 74 \\
\hline Yes & 316 & 155 \\
\hline
\end{tabular}

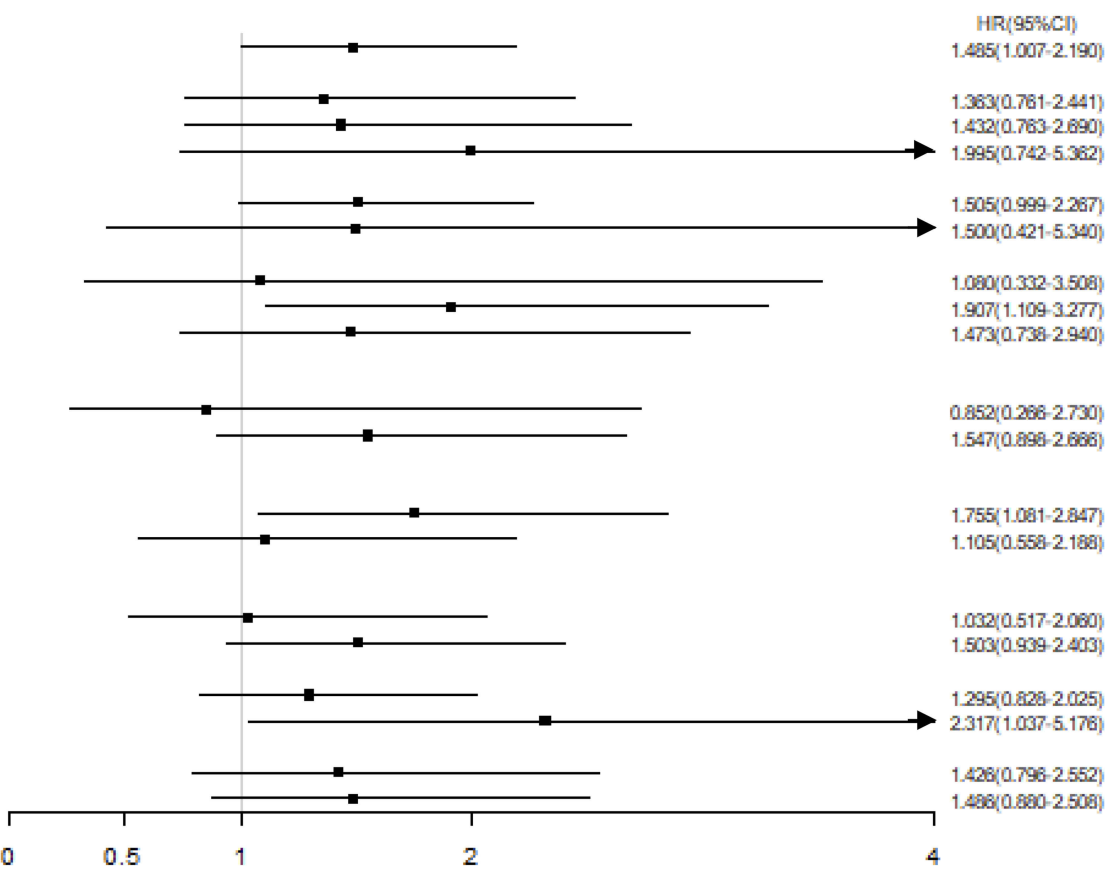

\section{B. Subgroup analysis of DSS}

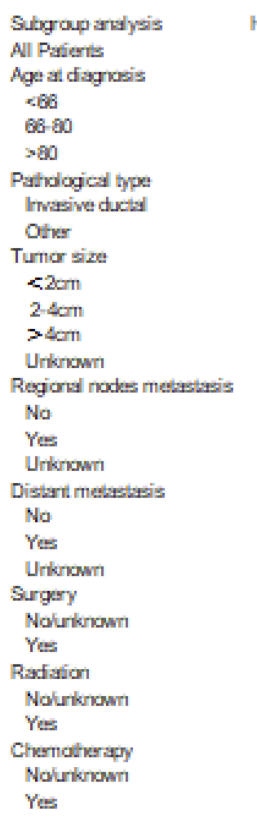

$\begin{array}{cc}\text { HER2 negrive } & \text { HER2 posifive } \\ 454 & 229 \\ 252 & 137 \\ 173 & 74 \\ 29 & 18 \\ 434 & 214 \\ 20 & 15 \\ 127 & 65 \\ 249 & 117 \\ 84 & 37 \\ & \\ 165 & 86 \\ 242 & 103 \\ & \\ 399 & 195 \\ 47 & 25 \\ & \\ 47 & 35 \\ 407 & 194 \\ 334 & 173 \\ 120 & 56 \\ 139 & 74 \\ 316 & 155 \\ & \end{array}$

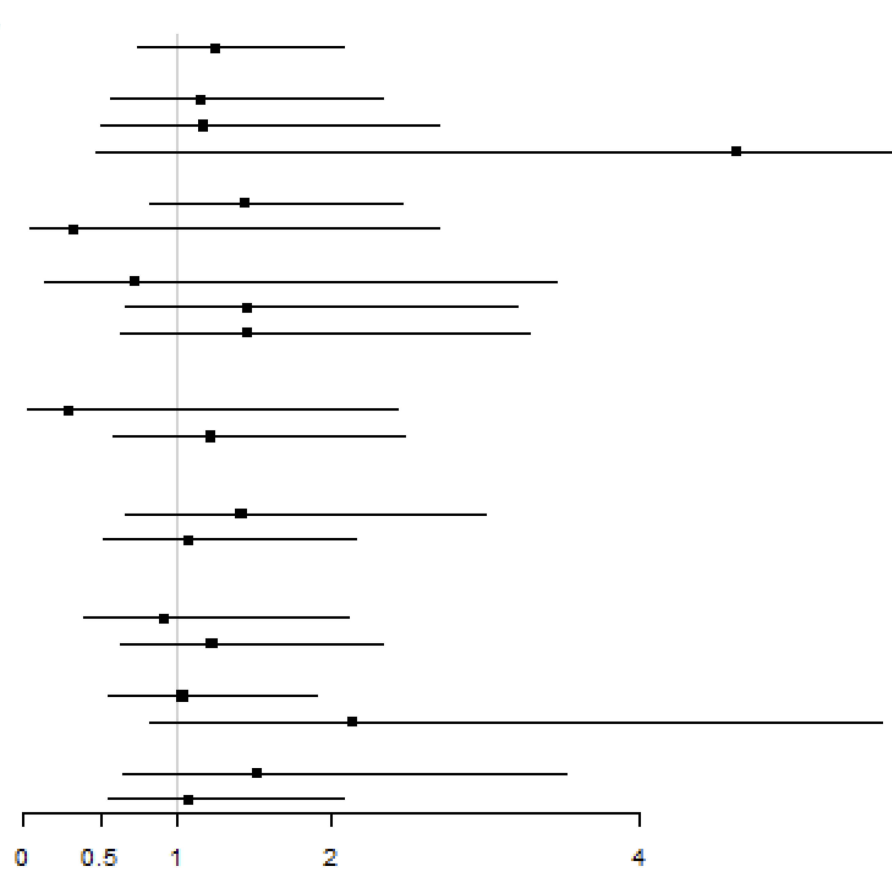

HR(95\%CI) $1.241(0.743-2.075)$

$1.145(0.563-2.328)$ 1. $168(0.505-2.694)$ $4.620(0.450-44.42)$

$1.429(0.8022 .453)$ $0.323(0.0392 .698 \%$

$0.717(0.1493 .454)$ $1.451(0.858-3200)$ 1.445 (0.635-3209?

0.296 (0.008-2.424) $1.207(0.5602 .2478)$

$1.412(0.606-2.994)$ 1.065 (0.525-2.159)

$0.911(0.394-2.100)$ $1220(0.636-2309)$

$1.030<0.556-1.910\rangle$ $2.139(0.822-5.564)$

$1.512(0.869-3.525)$ 1.075 (0.557-2.076)

Figure 3 Subgroup analysis of OS (A) and DSS (B) according to different HER2 status.

worse OS (85 vs 144 months). The study only included nonmetastatic MBC patients, which may be the reason for different results in the current study. In addition, the current study also found that HER2-negative MBC patients with a tumor size of $2-4 \mathrm{~cm}$, patients who had no distant metastasis, and patients who were receiving radiotherapy could obviously benefit from OS. Therefore, HER2 status can be considered as a feature for selecting benefit subgroups.

Compared with FBC patients, MBC patients are more likely to die from other causes. ${ }^{28}$ Data have shown that 
about $40 \%$ of men with breast cancer die from diseases other than cancer. ${ }^{4}$ Previous studies have shown that the 5 -year and 10-year OS rates for MBC patients are $65 \%$ and $38 \%$, whereas the 5-year and 10-year DSS rates are $74 \%$ and $51 \%$, respectively. ${ }^{29} \mathrm{~A}$ match of $53 \mathrm{MBC}$ patients with the same number of FBC patients indicated that although there was no difference in OS rates, $\mathrm{MBC}$ patients had higher DSS rates than women. ${ }^{28}$ Some studies suggest that DSS is more likely to reflect the prognosis of MBC patients, and OS may not be the most accurate endpoint in survival outcome. A previous study showed that there was no significant difference in DSS between different HER2 status in MBC patients, which is consistent with the current study results. ${ }^{27}$ The current study also found that HER2 status was not an independent associated factor with DSS for MBC patients and none of the subgroup was found to have a significant difference in DSS between different HER2 status.

Interestingly, we found that there was a significant difference in OS but no difference in DSS between different HER2 status in univariable Cox regression analysis. Wei JL et $\mathrm{al}^{30}$ found that chemotherapy is independently associated with OS, but chemotherapy has no effect on DSS in MBC patients, which is the same as the current results. Besides, few studies analyzed OS and DSS of $\mathrm{MBC}$ at the same time. There might be some reasons to explain the divergence of results on OS and DSS in the current study. First, HER2-positive patients somehow had a high risk of dying from causes other than cancer. Second, we did not consider the hormone receptor status in the model, and so the conclusion might be partial. Therefore, our assumption needs to be confirmed by further studies. In the current study, there was no significance between HER2-positive and HER2-negative groups in multivariable Cox regression analysis. Therefore, our findings did not support HER2-positive as an independent prognostic factor for MBC patients. Although some studies have identified similarities between breast cancer in men and in postmenopausal women, there is increasing evidence suggesting that the differs in genetics and proteomics between men and women breast cancer patients. ${ }^{31}$ The function of HER2 gene in the genesis and development of MBC is still unclear. In contrast with FBC, HER2 gene may not play a key role in the biological behavior of $\mathrm{MBC}$, which could explain why there is no difference in DSS between HER2-positive and HER2-negative patients.

We acknowledge some limitations in the current study. First, this study did not include the basic information of patients such as race, marital status, insurance status, and other factors that may affect the prognosis of patients, resulting in introduced biases in this study. Second, there was no detailed information on adjuvant therapy, chemotherapy, endocrine therapy, targeted therapy, and biological therapy, which may have led to information biases. Finally, as a retrospective study, selection biases could not be avoided. Therefore, a higher level of evidence is needed to confirm the results of this study. Despite these limitations, SEER remains a valuable resource for determining the prognosis factors of cancer. To the best of our knowledge, this is the latest study to report the effect of HER2 status on the prognosis of MBC. The current study used PSM to remove confounding factors, which lead to results that are more convincing.

\section{Conclusion}

This study showed that HER2 status had a clear influence on OS in patients with $\mathrm{MBC}$, and there were a longer OS and a higher 4-year OS rate in the HER2negative group. In addition, we observed that HER2 status had no significant effect on DSS in patients with MBC. With the increasing incidence of $\mathrm{MBC}$, the effects of HER2 status on the prognosis of patients with MBC need to be confirmed by prospective clinical studies.

\section{Data availability statement}

All data are fully available within the paper without restriction.

\section{Acknowledgment}

This study was funded by the National Natural Science Foundation of China (Grant Nos. 81670123 and 81770169) and Hubei province Health and Family Planning Scientific Research Project (WJ2017Q007). We thank LetPub for its linguistic assistance during the preparation of this manuscript.

\section{Author contributions}

All authors contributed toward data analysis, drafting, and revising the paper; gave final approval of the version to be published; and agree to be accountable for all aspects of the work.

\section{Disclosure}

The authors report no conflicts of interest in this work. 


\section{References}

1. Bray F, Ferlay J, Soerjomataram I, Siegel RL, Torre LA, Jemal A. Global cancer statistics 2018: GLOBOCAN estimates of incidence and mortality worldwide for 36 cancers in 185 countries. CA Cancer J Clin. 2018;68(6):394-424. doi:10.3322/caac.21492

2. Siegel RL, Miller KD, Jemal A. Cancer statistics, 2017. CA Cancer J Clin. 2017;67:7-30. doi:10.3322/caac.21387

3. Weiss JR, Moysich KB, Swede H. Epidemiology of male breast cancer. Cancer Epidemiol Biomarkers Prev. 2005;14(1):20-26.

4. Giordano SH, Cohen DS, Buzdar AU, Perkins G, Hortobagyi GN. Breast carcinoma in men: a population-based study. Cancer. 2004;101(1):51-57. doi:10.1002/cncr.20312

5. Klapper LN, Glathe S, Vaisman N, et al. The ErbB-2/HER2 oncoprotein of human carcinomas may function solely as a shared coreceptor for multiple stroma-derived growth factors. Proc Natl Acad Sci U S A. 1999;96(9):4995-5000. doi:10.1073/pnas.96.9.4995

6. Ross JS, Slodkowska EA, Symmans WF, Pusztai L, Ravdin PM, Hortobagyi GN. The HER-2 receptor and breast cancer: ten years of targeted anti-HER-2 therapy and personalized medicine. Oncologist. 2009;14(4):320-368. doi:10.1634/theoncologist.2008-0230

7. Hsu JL, Hung MC. The role of HER2, EGFR, and other receptor tyrosine kinases in breast cancer. Cancer Metastasis Rev. 2016;35 (4):575-588. doi:10.1007/s10555-016-9649-6

8. Spector NL, Blackwell KL. Understanding the mechanisms behind trastuzumab therapy for human epidermal growth factor receptor 2positive breast cancer. J Clin Oncol. 2009;27(34):5838-5847. doi:10.1200/JCO.2009.22.1507

9. Piccart-Gebhart MJ, Procter M, Leyland-Jones B, et al. Trastuzumab after adjuvant chemotherapy in HER2-positive breast cancer. $N$ Engl $J$ Med. 2005;353(16):1659-1672. doi:10.1056/NEJMoa052306

10. Romond EH, Perez EA, Bryant J, et al. Trastuzumab plus adjuvant chemotherapy for operable HER2-positive breast cancer. $N$ Engl $J$ Med. 2005;353(16):1673-1684. doi:10.1056/NEJMoa052122

11. Slamon D, Eiermann W, Robert N, et al. Adjuvant trastuzumab in HER2-positive breast cancer. N Engl J Med. 2011;365(14):12731283. doi:10.1056/NEJMoa0910383

12. Korde LA, Zujewski JA, Kamin L, et al. Multidisciplinary meeting on male breast cancer: summary and research recommendations. $J$ Clin Oncol. 2010;28(12):2114-2122. doi:10.1200/JCO.2009.25.5729

13. Ottini L, Capalbo C, Rizzolo P, et al. HER2-positive male breast cancer: an update. Breast Cancer (Dove Med Press). 2010;4(2):45-58.

14. Rudlowski C, Friedrichs N, Faridi A, et al. HER-2/neu gene amplification and protein expression in primary male breast cancer. Breast Cancer Res Treat. 2004;84(3):215-223. doi:10.1023/B:BREA. $0000019953.92921 .7 \mathrm{e}$

15. Rudlowski C, Rath W, Becker AJ, Wiestler OD, Buttner R. Trastuzumab and breast cancer. N Engl J Med. 2001;345(13):997-998.

16. Carmona-Bayonas A. Potential benefit of maintenance trastuzumab and anastrozole therapy in male advanced breast cancer. Breast. 2007;16(3):323-325. doi:10.1016/j.breast.2006.12.010
17. Hayashi H, Kimura M, Yoshimoto N, et al. A case of HER2-positive male breast cancer with lung metastases showing a good response to trastuzumab and paclitaxel treatment. Breast Cancer. 2009;16 (2):136-140. doi:10.1007/s12282-008-0060-1

18. Muir D, Kanthan R, Kanthan SC. Male versus female breast cancers: a population-based comparative immunohistochemical analysis. Arch Pathol Lab Med. 2003;127(1):36-41. doi:10.1043/0003-9985(2003) $127<36$ :MVFB $>2.0 . \mathrm{CO} ; 2$

19. Liu N, Johnson KJ, Ma CX. Male breast cancer: an updated surveillance, epidemiology, and end results data analysis. Clin Breast Cancer. 2018;18(5):e997-e1002.

20. Greif JM, Pezzi CM, Klimberg VS, Bailey L, Zuraek M. Gender differences in breast cancer: analysis of 13,000 breast cancers in men from the National Cancer Data Base. Ann Surg Oncol. 2012;19 (10):3199-3204. doi:10.1245/s10434-012-2479-z

21. Anderson WF, Jatoi I, Tse J, Rosenberg PS. Male breast cancer: a population-based comparison with female breast cancer. J Clin Oncol. 2010;28(2):232-239. doi:10.1200/JCO.2009.23.8162

22. Miao H, Verkooijen HM, Chia KS, et al. Incidence and outcome of male breast cancer: an international population-based study. $J$ Clin Oncol. 2011;29(33):4381-4386. doi:10.1200/JCO.2011.36. 8902

23. Gucalp A, Traina TA, Eisner JR, et al. Male breast cancer: a disease distinct from female breast cancer. Breast Cancer Res Treat. 2019;173(1):37-48. doi:10.1007/s10549-018-4921-9

24. Chavez-Macgregor M, Clarke CA, Lichtensztajn D, Hortobagyi GN, Giordano SH. Male breast cancer according to tumor subtype and race: a population-based study. Cancer. 2013;119(9):1611-1617. doi:10.1002/cncr. 27905

25. Giordano SH. Breast cancer in men. $N$ Engl J Med. 2018;378 (24):2311-2320. doi:10.1056/NEJMra1707939

26. Leone JP, Leone J, Zwenger AO, Iturbe J, Vallejo CT, Leone BA. Prognostic significance of tumor subtypes in male breast cancer: a population-based study. Breast Cancer Res Treat. 2015;152(3):601609. doi:10.1007/s10549-015-3488-y

27. Arslan UY, Oksüzoğlu B, Ozdemir N, et al. Outcome of non-metastatic male breast cancer: 118 patients. Med Oncol. 2012;29(2):554560. doi:10.1007/s12032-011-9978-9

28. EI-Tamer MB, Komenaka IK, Troxel A, et al. Men with breast cancer have better disease-specific survival than women. Arch Surg. 2004;139(10):1079-1082. doi:10.1001/archsurg.139.10.1079

29. Cutuli B, Lacroze M, Dilhuydy JM, et al. Male breast cancer: results of the treatments and prognostic factors in 397 cases. Eur J Cancer. 1995;31A(12):1960-1964. doi:10.1016/0959-8049(95)00366-5

30. Wei JL, Zhang JX, Fu DY. Characterization and prognosis of estrogen receptor-positive/progesterone receptor-negative male breast cancer: a population-based study. World J Surg Oncol. 2018;16(1):236. doi:10.1186/s12957-018-1539-7

31. Zografos E, Anagnostopoulos AK, Papadopoulou A, et al. Serum proteomic signatures of male breast cancer. Cancer Genomics Proteomics. 2019;16(2):129-137. doi:10.21873/cgp.20118
OncoTargets and Therapy

\section{Publish your work in this journal}

OncoTargets and Therapy is an international, peer-reviewed, open access journal focusing on the pathological basis of all cancers, potential targets for therapy and treatment protocols employed to improve the management of cancer patients. The journal also focuses on the impact of management programs and new therapeutic agents and protocols on patient perspectives such as quality of life, adherence and satisfaction. The manuscript management system is completely online and includes a very quick and fair peer-review system, which is all easy to use. Visit http://www.dovepress.com/ testimonials.php to read real quotes from published authors. 